\title{
RELEVANSI NILAI AKUNTANSI \\ AKRUAL VERSUS KAS
}

\author{
M. Ali Fikri \\ Universitas Mataram \\ fikri.sampala@unram.ac.id \\ Zuhrotul Isnaini \\ Universitas Mataram \\ zuhrotul.isnaini@unram.ac.id \\ Rahmi Sri Ramadhani \\ Universitas Mataram \\ rahmisri.ramadhani@unram.ac.id
}

$\begin{array}{ll}\text { Diterima } & : \text { 11 Juni } 2020 \\ \text { Direview } & : \text { 14 Juni } 2020 \\ \text { Diterima } & : \text { 14 Juni } 2020\end{array}$

\begin{abstract}
Value relevance specifically explains the relationship between the dependent variable, which is based on the price of a security, and the independent variable of accounting information. There are two common measurement methods used by investors to determine the value of accounting information, namely the profit and loss approach and the balance sheet approach which are both accrual-based. This study uses a qualitative approach, which employed respondents of lecturers of Capital Market subjects, Accountants/consultants, and members of the IAI of NTB Region. The results of the study generally states that the accrual approach has a small impact on changes in stock prices and different from the cash flow.
\end{abstract}

Keywords: value relevance, accrual, operating cash flow. 


\section{Abstrak}

Relevansi nilai secara spesifik menjelasakan hubungan antara variabel dependen yang berbasis harga sekuritas dan variabel independen informasi akuntansi. Terdapat dua cara pengukuran umum yang digunakan investor untuk menentukan nilai infomasi akuntansi, yaitu pendekatan rugi laba dan pendekatan neraca yang keduanya berbasis accrual. Penelitian menggunakan pendekatan kualitatif dengan responden penelitian Tenaga Pengajar (Dosen) yang berkecimpung dalam mata kuliah Pasar Modal, Akuntan Berpraktek/konsultan, dan anggota IAI Wilayah NTB, hasil penelitian secara umum menyatakan bahwa pendekatan akrual memiliki dampak kecil terhadap perubahan harga saham, berbeda dengan arus kas.

\section{Kata Kunci: Relevansi Nilai, akrual, arus kas operasi}

\section{PENDAHULUAN}

Riset relevansi nilai secara spesifik melakukan pengujian argumentasi melalui prediksi asosiasi antara variabel dependen yang berbasis harga sekuritas dan variabel independen informasi akuntansi. Angka akuntansi dianggap memiliki nilai relevan bila secara signifikan berhubungan dengan variabel dependen. Riset relevansi nilai didasarkan pada dua kombinasi basis teoritis, yaitu valuation theory dan argumen kontekstual akuntansi tentang bagaimana variabel akuntansi berhubungan dengan nilai pasar ekuitas (Beaver, 2002). Riset relevansi nilai mengombinasikan pendekatan nilai buku dan laba akuntansi.

Riset relevansi nilai (misalnya, Jones, 1991; Ohlson, 1995; Dechow et al., 1995; Burgstahler dan Dichev, 1997; Francis dan Schipper, 1999; Barth et al., 1999; Marquardt dan Wiedman 2004) menyatakan relevansi nilai bergantung dari kualitas informasi yang tersedia. Ketersediaan informasi yang disajikan akan direspon investor untuk menilai kinerja perusahaan (Subramanyam, 1996; Beaver, 2002). Permasalahan yang berhubungan dengan relevansi nilai, 
yaitu apakah kualitas informasi yang disajikan sesuai kondisi perusahaan sesungguhnya.

Kualitas informasi berhubungan dengan perilaku penyusun laporan, yaitu pihak manajemen karena laporan keuangan merupakan bentuk tanggung jawab manajemen atas sumber daya pemilik. Akses informasi internal dan prospek perusahaan di masa mendatang yang dimiliki lebih banyak oleh manajemen dibandingkan investor dapat menimbulkan asimetri informasi. Kondisi ini dapat mendorong pihak manajemen berperilaku opportunistic dan memilih kebijakan akuntansi sesuai dengan kepentingannya, di samping standar akuntansi memberikan fleksibilitas untuk memilih seperangkat kebijakan jika kinerja manajemen diukur berdasarkan laba (Healy, 1985). Perilaku disfunctional behaviour ini disebut sebagai perilaku manajemen laba (earning management).

Konsekuensi perilaku manajemen laba ini, yaitu laporan keuangan tidak lagi mencerminkan kondisi sesungguhnya dan menyebabkan investor tidak bisa menyandarkan diri sepenuhnya pada informasi yang disajikan untuk mengukur kinerja perusahaan (Marquardt dan Wiedman, 2004). Untuk menjamin ketersediaan informasi yang lebih baik, pihak investor berusaha mencari metode alternatif lain mengukur kinerja perusahaan, yaitu arus kas.

Ohlson (1995), Solomon (1995), Brugstahler dan Dichev, (1997), Collins et al. (1997), Francis dan Schipper (1999), Barth et al. (1999), Beaver (2002), dan Marquardt dan Wiedman (2004) menyatakan terdapat dua cara pengukuran umum yang digunakan investor untuk menentukan nilai infomasi akuntansi, yaitu pendekatan rugi laba dan pendekatan neraca. Pendekatan rugi laba diukur berdasarkan nilai laba sedangkan pendekatan neraca diukur berdasarkan nilai buku. Meskipun demikian, terdapat pertentangan tentang relevansi nilai berdasarkan pendekatan laba dan nilai buku (Solomons, 1995). Solomons (1995) menyatakan pendekatan neraca lebih berguna menilai 
perusahaan dibandingkan pendekatan laba karena menggambarkan kondisi sumber daya perusahaan dengan lebih tepat. Barth dan Landsman (1995) menyatakan dalam pasar yang sempurna, fair value accounting based balance sheet lebih menyajikan seluruh informasi yang relevan, sedangkan income statement memberikan informasi yang terlalu berlebihan dan realisasi income yang tidak relevan. Brugstahler dan Dichev (1997), Francis dan Schipper (1999), dan DeFond (2002) menyatakan pendekatan nilai buku lebih dipercaya oleh pihak investor dibandingkan dengan pendekatan laba dengan alasan laba memberikan informasi operasi perusahaan per periode, sedangkan nilai buku memberikan informasi nilai bersih sumber daya perusahaan jangka panjang. Selain itu nilai buku mengandung unsur kas dan setera kas.

Relevansi nilai menurut Beaver (1968) merupakan explanatory power dari informasi akuntansi, misalnya laba akuntansi dan nilai buku hubungannya dengan nilai perusahaan yang direpresentasikan dengan harga saham. Angka akuntansi dianggap sebagai nilai yang relevan bila secara signifikan berhubungan dengan variabel dependen dan informasi laba rugi dan neraca merupakan bentuk relevansi nilai yang tercermin dalam harga saham.

Penelitian ini merupakan pengembangan studi sebelumnya yang dilakukan oleh Bruhstahler dan Dichev (1997), Collins et al. (1997), Rangan (1998), Teoh et al. (1998), Francis dan Shipper (1999), Barth et al. (1999), Lev dan Zarrowin (1999), Dontoh et al., (2004), dan Marquardt dan Weidman (2004) yang menjelaskan hubungan relevansi nilai dengan menambahkan informasi arus kas operasi.

\section{TELAAH LITERATUR}

Manajemen laba merupakan cara yang digunakan manajemen untuk meningkatkan nilai laporan keuangan. Scott (2003) menyatakan terdapat banyak alasan yang mendasari manajemen melakukan manajemen laba. 
Manajemen laba dapat dilihat dari perspektif teori kontrak dan perspektif laporan keuangan. Dilihat dari sisi teori kontrak, manajemen laba dapat digunakan sebagai jalan untuk memperkecil biaya untuk melindungi perusahaan dari konsekuensi kontrak yang dilakukan. Dari sisi laporan keuangan manajer dapat mengubah nilai pasar perusahaan melalui tindakan manajemen laba.

Manajer dapat memilih berbagai kebijakan akuntansi untuk mengambil kebijakan memaksimalkan nilai perusahaan. Healy (1985) menjelaskan dan memprediksi perilaku manajer dalam melakukan pilihan terhadap kebijakan akuntansi. Hasil temuannya menyatakan manajer perusahaan cenderung untuk meningkatkan earnings perusahaan berdasarkan bonus plan. Dikatakan juga bahwa net income memotivasi manajer menggunakan kebijakan akuntansi agar income barada di antara bogey dan cap. Healy juga menjelaskan perilaku manajer melakukan kontrol terhadap net income melalui kontrol terhadap akrual dan perubahan kebijakan akuntansi.

Beberapa motivasi manajer melakukan manajemen laba di samping rencana bonus, di antaranya yaitu:

a. Motivasi Kontraktual

Manajer melakukan manajemen laba jika terdapat kontrak perjanjian antara perusahan dengan manajer untuk manaikkan earnings.

b. Motivasi Politik

Perusahaan bersekala besar dengan aktivitas yang terkait dengan banyak individu cederung untuk mengurangi biaya politik mereka dengan cara menerapkan kebijakan akuntansi tertentu, misalnya kebijakan akuntansi politik untuk mengurangi pelaporan net income yang terlalu tinggi ketika laba perusahaan besar agar tidak terlihat terlalu mencolok.

c. Motivasi Pajak 
Fikri, Isnaini E Ramadhani: Relevansi Nilai Akuntansi ...

Manajer mengambil keputusan tertentu untuk mengurang pajak yang dibayarkan, misalnya penggunaan metoda perhitungan persediaan dengan menggunakan metoda LIFO atau FIFO.

d. Perubahan CEO

Hipotesis bonus plan memprediksi pengunduran diri CEO merupakan strategi untuk meningkatkan pendapatan perusahaan dan upaya meningkatkan bonus manajer tersebut.

e. Initial publik offering (IPO)

Pada penerbitan saham awal (IPO), perusahaan biasanya tidak memiliki patokan harga saham. Informasi akuntansi dapat digunakan memprediksi dan menentukan harga saham.

f. Untuk mengkominikasikan informasi kepada investor

Pola dari manajemen laba menurut Scott (2003) yaitu:

\section{a. Taking a Bath}

Terjadi pada saat organisasi mengalami tekanan atau reorganisasi, misalnya menyewa CEO baru. Manajer yang tidak dapat meningkatkan net income di atas bogey akan melakukan taking a bath dan menyimpan bonus untuk periode berikutnya dengan cara menghapus earning ke depan dan menyimpannya untuk keperluan mendatang.

b. Minimalisasi Pendapatan

Perusahaan dengan laba yang terlalu besar dengan alasan tertentu akan mengurangi labanya.

c. Maksimalisasi Pendapatan

Perusahaan mungkin terikat pada pola maksimalisasi pendapatan bersih dan berusaha untuk memaksimalkan laporan untuk meningkatkan bonus.

d. Income Smoothing

Manajer memiliki insentif untuk melaporkan income secara tepat pada posisi antara bogey dan cap. 
Beberapa literatur dan penelitian yang berhubungan dengan manajemen laba dan relevansi nilai (Solomons, 1995; Rangan, 1998; DeFond, 2002; Barth et al., 1999; Marquardt dan Wiedman, 2004) menyatakan relevansi nilai dari informasi akuntansi dipengaruhi oleh perilaku manajemen laba. Relevansi nilai secara umum dihasilkan dari dua model pengukuran yaitu berdasarkan laporan rugi laba dan neraca. Perusahaan yang melakukan manajemen laba umumnya memiliki relevansi nilai yang lebih kecil dibandingkan yang tidak melakukannya, dan investor lebih menyukai mengukur relevansi nilai perusahaan berdasarkan pendekatan neraca (nilai buku) dibandingkan rugi laba (net income) karena diasumikan pendekatan rugi laba memiliki unsur akrual lebih banyak dan hanya mengukur kinerja perusahaan per periode. Penelitian ini mencoba mengembangkan pendekatan lain dengan memasukkan unsur penlian arus kas operasi dalam analisis.

\section{Penelitian Relevansi Nilai}

Manajemen laba merupakan implementasi kebijakan yang menyebabkan elemen yang digunakan untuk membuat keputusan menjadi kurang bermakna atau implementasi yang tidak konsisten dengan standar (Schipper, 1999 dalam Fields et al., 2001). Healy dan Wahlen (1999) menyatakan manajemen laba terjadi ketika kebijakan manajemen terhadap laporan keuangan, mengubah struktur laporan keuangan yang menyebabkan stakeholder bias menilai kinerja ekonomi perusahaan atau mempengaruhi outcome contractual yang tergantung pada pelaporan angka akuntansi. Manajemen laba dapat digunakan untuk menyembunyikan informasi privat atau mengubah bentuk laporan laba sesuai keinginan manajemen (Watts dan Zimmerman, 1986). Seperti yang dinyatakan oleh Marquardt dan Wiedman (2004), konsekuensi perilaku manajemen laba ini menjadikan laporan keuangan tidak lagi 
mencerminkan kondisi yang sesungguhnya dan menyebabkan pihak investor tidak bisa menyandarkan diri pada informasi yang disajikan untuk mengukur kinerja perusahaan. Untuk menjamin ketersediaan informasi yang lebih baik, pihak investor berusaha mencari metoda alternatif lain mengukur kinerja perusahaan yaitu berdasarkan laba dan nilai buku.

DeFond (2002) menyatakan penelitian yang berhubungan dengan manajemen laba cenderung difokuskan pada income ststement sebagai implikasi dari tindakan manajemen laba pada proses akuntansi. Partisipan pasar (investor) lebih menyukai penggunaan informasi yang berasal dari neraca karena membantu lebih memahami memprediksi earnings perusahaan ke depan.

Brugstahler dan Dichev, (1997) melakukan uji model penilaian earnings dan nilai buku terhadap nilai pasar perusahaan menggunakan data penelitian dari tahun 1976-1994. Penelitiannya menggunakan variabel market value $(\mathrm{MV})$, book value (BV), dan earnings (E), serta menggunakan varaibel perubahan MV, BV, dan E secara cross section dan pooled. Hasil penelitiannya menggunakan cross section dan pooled menemukan nilai variabel earnings yang siginfikan untuk seluruh regresi sampel, sesuai dengan teori relevansi nilai atas earnings dan menemukan penurunan nilai $\mathrm{R}^{2}$ dari tahun 1976 sampai dengan tahun 1994. Brughstaler dan Dichev (997) menggunakan variabel perubahan MV, BV, dan E serta variabel kontrol middle range (DM) dan high range $(\mathrm{DH})$ yang diperoleh dari cutoff E/BV juga menunjukkan hasil yang konsisten, yaitu nilai buku lebih berguna menentukan nilai saham perusahaan dibandingkan dengan earnings jika nilai earnings/book value rendah dan earnings berguna untuk menentukan nilai perusahaan jika terjadi peningkatan earnings setiap tahunnya.

Francis dan Schipper (1999) menguji relevansi nilai informasi akuntansi menggunakan data tahun 1952-1994. Penelitiannya menggunakan pengukuran relevansi nilai dari variabel SIGN_EARN dan $\triangle E A R N$ sebagai proksi 
dari laporan rugi laba, dan $\triangle \mathrm{CASH}$, RATIO 1, RATIO 2, ASSET, dan LIAB sebagai proksi dari neraca. Hasil penelitiannya menemukan relevansi nilai return berdasarkan earnings mengalami penurunan, sedangkan relevansi nilai return nilai asset dan liability, dan kombinasi nilai buku aset dan liabilities dan earnings tidak mengalami penurunan. Kesimpulan penelitiannya yaitu pendekatan nilai buku memiliki relevansi nilai lebih tinggi dibandingkan pendekatan earnings.

Marquardt dan Wiedman (2004) meneliti apakah oportunisasi perilaku manajemen laba berpengaruh terhadap relavansi nilai net income dan nilai buku. Penelitiannya menggunakan model discretionary accrual Jones (1991) untuk menyeleksi sampel perusahaan yang melakukan manajemen laba dan tidak melakukan manajemen laba pada perusahaaan yang melakukan equity offering dengan sampel sebanyak 192 pada tahun 1984-1991. Variabel net income (NI), book value (BV) serta beberapa variabel kontrol SIZE, GROWTH, dan LEVERAGE digunakan dalam penelitiannya. Hasilnya menemukan net income memiliki relevansi lebih rendah dibandingkan nilai buku.

\section{METODE PENELITIAN}

\section{Jenis, Lokasi, dan Metode Pengumpulan dan Analisis Data Penelitian}

Penelitian ini merupakan penelitian dengan menggunakan pendekatan kualitatif. Analisis dimaksudkan untuk menggambarkan fenomena yang terjadi di lapangan menggunakan data wawancara dari tenaga ahli yang bergelut di bidang akuntansi maupun pasar modal. Lokasi penelitian dilakukan di Mataram dengan responden dosen, akuntan berpraktek dan anggota IAI Wilayah.

Hampir sama dengan metode riset lainnya, penelitian ini menggunakan serangkaian proses dan teknik untuk melakukan penggalaian data di lapangan. Kehadiran peneliti untuk berinteraksi dengan subjek diharapkan 
memberi pemahaman lebih utuh penelitian melalui wawancara partisipan untuk melihat secara langsung perilaku yang berhubungan dengan fenomena yang diamati (Sanders, 1982, Saerang, 2001, 87). Penggalian data di lapangan peneliti lakukan dengan cara teknik analisis wawancara kepada tenaga pengajar (dosen) yang berkecimpung dalam mata kuliah Pasar Modal, Akuntan Berpraktek/konsultan, dan anggota IAI Wilayah NTB.

\section{HASIL PENELITIAN DAN PEMBAHASAN}

Responden penelitian dosen akuntansi menyatakan secara alami kedua pendekatan merupakan pendekatan yang sama. Bagi pelaku yang memahami laporan keuangan, pelaku pasti akan menggunakan kedua pendekatan, baik neraca dan laba rugi, karena keduanya tidak bisa dipisahkan.

Laba hanya perdiksi sementara, sedangkan neraca merupakan komponen menyeluruh. Pada ujungnya laba akan dikapitalisasi dalam neraca, sebagaimana dinyatakan oleh dosen pengampu mata kuliah pasar modal.

"secara teori ada beberpa penelitian yang menyatakan terjadi penurunan nilai relevansi akuntansi. Namun, penurunan itu masih sulit dibedakan apakah berdasarkan pendekatan laba rugi atau pendekatan neraca. Kedua pendekatan sama. Intinya adalah pada jumlah laba ditahan, apakah cukup dibagi atau tidak. Laba hanya sebagai prediksi saja, faktanya neraca yang banyak memiliki peran."

"tidak ada perbedaan antara keduanya. Penurunan relevansi nilai kebanyakan deisebabkan oleh faktor lain selain akuntansi"

Responden pengamat pasar modal menyatakan sudah sifat menusia memperoleh keuntungan, tetapi perlu diingat, laba yang dimaksud adalah bukan laba accrual, tapi laba berbentuk kas. Semua sumber ekonomi digerakkan oleh kas, bukan akuntansi. Akuntansi hanya sebagai media catat mencatat. Faktanya di lapangan semua membutuhkan kas. 
"yang terpenting adalah arus kas, bukan laba atau neraca. Investor membutuhkan kas, bukan piutang."

"terlalu banyak kasus accrual dalam akutansi, sejak kasus Enron, kepercayaan akan accrual menurun. Apalagi ditambah dengan kasus laporan keuangan Garuda."

Responden Akuntan berpraktek menyatakan sumber ekonomi digerakkan oleh kas, bukan akuntansi.

"arus kas adalah faktor utama."

"Investor nggak pernah lihat laba atau neraca, yang banyak dilihat prospek pasar dan trend harga saham. Pasar susah seperti ini banyak terjadi trend harga turun

"Jika saya malah bukan ketiganya. Penyebab membeli saham itu karena sayang uang menganggur atau karena rayu broker"

dan responden pelaku pasar modal menyatakan:

"Mungkin bukan laba atau neraca, tapi rasio keuangan, PER dan PBV, utk lihat kemurahan atau kemahalan"

Beberapa hasil wawancara mengenai Relevansi sebgai kekuatan penjelas secara menyeluruh dari informasi akuntansi terhadap harga saham mendukung sekaligus menolak beberapa hasil penelitian sebelumnya, seperti Brugstahler dan Dichev (1997), Barth et al. (1999), Rangan (1998), Francis dan Schipper (1999), Teoh et al. (1998), Dontoh et al. (2004), dan Marquardt dan Wiedman (2004) yang menemukan nilai variabel earnings berpengaruh terhadap perubahan harga saham, namun mendukung penelitian Collins et al. (1997) yang menyatakan kombinasi relevansi nilai berdasarkan pendekatan earnings dan nilai buku tidak mengalami berpengaruh terhadap penilaian investor. Penjelas yang paling spesifik adalah kas yang mereka terima bukan pendapatan accrual. 
Penelitian ini meneliti relevansi nilai akuntansi accrual dan kas. Hasil penelitian secara umum menyatakan bahwa pendekatan laba dan Neraca memiliki dampak kecil terhadap perubahan harga saham, kecuali arus kas. Penelitian ini dilakukan di sekitar ruang lingkup dosen, praktisi, dan pelaku pasar modal dengan jumlah sampel yang tidak banyak. Namun demikian pemilihan sampel ini dilakukan dengan menggunakan masukan dan saran dari responden yang telah berkecimpung dalam pengelolaan pasar modal. Selanjutnya diharapkan responden dapat diperbanyak dengan menggunakan pihak penerima keuntuangan atas transaksi sehingga terlihat kejelasan yang lebih baik kegunaan dari laporan keuangan di pasar modal.

Penelitian ini memiliki beberapa implikasi. Pertama, secara teoritis penelitian ini memberikan gambaran secara umum bahwa kas lebih bermakna terhadap prediksi return saham. Kedua, secara praktis dapat sebagai masukan bagi pelaku pasar modal dalam mengambil keputusan, dan Ketiga, hasil ini memiliki impikasi bagi pengambil kebijakan, bahwa kepastian return terutama kas/arus kas merupakan hal yang harus dijelaskan dalam laporan keuangan.

\section{DAFTAR PUSTAKA}

Ball, R. and P. Brown.1968. An Empirical Evaluation of Accounting Income Numbers. Journal of Accounting Research. Vol. 6 (Autumn). pp. 159-178 Barth, M.E., and WR Landsman. 1995. Fundamental Issues Related to Using Fair Value Accounting for Financial Reporting. Accounting Horizon. Vol. 9 No. 4. pp. 97-107.

Barth, ME., John A. Elliot, and Mark W. Finn. 1999. Market Rewards Associated With pattern on Increasing Earning. Journal of Accounting Research. Vol. 2 (Autumn). pp. 387-413. 
Barth, ME., W.H. Beaver and W.R. Landsman. 2001. The Relevance of Value Relevance Research for Financial Accounting Standard Setting: Another View. Journal of Accounting and Economics. Vol. 39 (September). pp. 77-104.

Beaver, William H. 1968. The Information Content of Earnings. Journal of Accounting Research. Vol. 6 (supplement) pp. 67-92.

Beaver, William H. 2002. Perspectives on Recent Capital Market Research. The Accounting Review. Vol 7 (2) April. pp. 453-474.

Brown, Stephen., Kin Lo and Thomas Lys. 1999. Use of $R^{2}$ in Accounting Research: Measuring Changes in Value Relevance Over the Last Four Decades. Journal of Accounting and Economics. Vol. 28. pp. 83-115.

Burgstahler, D. and I. Dichev, 1997, Earning, Adaption, and Equity Value, The Accounting Review, vol 72 pp187-215.

Capstaff, John, Khrisna Paudyal, and William Rees. 1998. Earnings Forecasts and the Earnings to Price Relationship.rees@accfin.gla.ac.uk.

Collins, Daniel W., Edward L. Maydew, and Ira S. Weiss. 1997. Changes in the Value Relevance of Earnings and Book Values Over the Past Forty Years. Journal of Accounting and Economics. Vol. 24. pp. 39-67.

Coram, Paul. 2004. An Experimental Evaluation of the Effect of Voluntary Disclosure of Non-Financial Performance Indicators and Assurance on this Information on Stock Price Estimation and Earnings Forecasts. Paper from PhD. Dissertation. Australian National University.

Cooper, Donald R. dan C.William Emory. 1996, Metode Penelitian Bisnis, Terjemahan, Jilid 1, Edisi 5, Erlangga, Jakarta.

Dechow, P, R. Sloan and Sweeney, 1995. Detecting Earning Management. The Accounting Review. Vol 70 pp.193-226.

DeFond, Mark L., 2002. Discussion of the Balance Sheet as an Earnings Management Constraint. The Accounting Review. Vol 77 pp.29-33. 
Fikri, Isnaini \& Ramadhani: Relevansi Nilai Akuntansi ...

Dontoh, Alex., Suresh Radhakrishnan and Joshua Ronen. 2004. The Declining Value Relevance of Accounting Information and Non-Information-Based Trading: An Empirical Analysis. Contemporary Accounting Research. Vol. 21 pp. 793-812.

Francis, Jennifer and Catherine Schipper. 1999. Have Financial Statements Lost Their Relevance. Journal of Accounting Research. Vol. 37 (2). pp. 319-352.

Fields D. Thomas, Thomas Z. Lys, and Linda Vincent. 2001. Empirical Research on Accounting Choice. Journal of Accounting and Economics. Vol. 31. pp. 255-307.

Gujarati, Damodar. 1998. Ekonometrika Dasar. Penerbit Erlangga. Jakarta.

Hair, J.F. Jr., R.E. Anderson, R.L. Tatham, W.C. Black. 1998, Multivariate Data Analysis, Fifth Edition, Pretice Hall International.

Healy, P., 1985. The The Impact of Bonus Scheme on Selection of Accounting Principles. Journal of Accounting and Economic.

Healy, P. And J.M. Wahlen. 1999. A Review of Earning Managements Literature and Its Implication for Standart Setting. Accounting Horizon Vol 13 pp.365-384.

Holthasen and Watss, 2001. The Relevance of Value Relevance Literatur for Financial Accounting Standar Setting. Journal of Accounting and Economic.

Jones, Jeniffer J. 1991. Earnings Management During Import Relief Investigation. Journal of Accounting Research, Vol 29 No 2 Autumn.

Lev, Baruch and Paul Zarowin. 1999. The Boundaries of Financial Reporting and How To Extend Them. Journal of Accounting Research. Vol. 37 (2). pp. 353-385.

Marquardt, Carol A. dan Christine I. Weidman, 2004. The Effect Of Earnings Management On Value Relevance Of Accounting Information. Journal of Business Finance and Accounting. 
Ohlson, James A. 1995. Earnings, Book Values, and Dividen in Equity Valuation. Contemporary Accounting Research, Vol 11 No 2 Spring.

Sloan, R., 1996. Do Stock Price fully Reflect Information in Accruals and Cash Flow About Future Earnings? The Accounting Review.

Scott, William R. 2003, Financial Accounting Theory, Pearson Education Canada Inc., Toronto, Ontario.

Subramanyam, K. R., 1996. The Pricing of Discretionary Accrual. Journal of Accounting and Economic. Vol 22 pp. 249-281.

Saerang, David Paul Elia (2001). Accountability and Accounting in a Religius Organization: an Interactive Ethnographic Study of the Pantecostal Chruch of Indonesia. Disertation University Wollonggong.

Sanders, Patricia (1982). Phenomenology: A New Way of Viewing Organizational Research. Academy of Management Review. Vol. 7 (3) pp 353-360.

Teoh Siew Hong, Ivo Welch, and T.J. Wong. 1998. Earning Management and the Underperformance of Seasoned Equity Offering. Journal of Financial Economic. Vol 50 pp.63-99.

Watts, R. Dan J. Zimmerman, 1986, Positive Accounting Theory, Englewood Cliff, New Jersey: Pertice Hall. 